\title{
TERRORISM AND ANTI-TERRORISM LEGISLATION IN CANADA
}

EXAMINING THE INFLUENCE OF THE UNITED STATES, THE

MEDIA, AND THE PSYCHOLOGICAL PHENOMENON OF TERROR ON CANADA'S DEMOCRATIC STATE

AMANDA SPITZIG

LS 401 - LAW, CULTURE AND RIGHTS

The events of September 11, 2001 drastically altered the way North Americans view the concepts of safety, security, and terrorism. The unprecedented events of this date left the citizens of the United States in shambles, as the mass media saturated the world with images of hopelessness and despair (Schuster, 2011). Over 3,000 individuals lost their lives when an AlQaeda terrorist group struck down the World Trade Centre buildings in New York City (O’Malley, 2003). The political agenda of the White House was rapidly amended, as politicians focused on increasing national security measures in order to put the minds of the American citizens at ease. Canadians were not left unaffected by these events, and rapid policy changes also occurred north of the border (Whitaker, 2003). These controversial policy changes sparked a debate among politicians, academics, and the Canadian citizens about whether these new pieces of legislation represented an appropriate response to the perceived threat of terrorism. Twelve years later this debate still holds strong, and Bill C-36, The Anti-terrorism Act (2001), and Bill S-7, the Combating Terrorism Act (2013), both of which address crimes associated with terrorist activity, are still under constitutional scrutiny.

This critical analysis paper will seek to explore both sides of this political and legal debate by tackling some of the major issues of concern in regards to anti-terrorism legislation. The hegemonic influence of the United States over Canada after the events of 9/11 will be examined 
alongside the pieces of legislation that came into effect as a result. The definition of terrorism itself will be dissected, with special focus on comparing the media portrayal of terrorism with the actual motives and objectives of modern terrorist acts. The psychological phenomenon of terror will be examined in order to determine whether terrorism is a real or perceived threat to society. Finally, we will return to Canada's anti-terrorism legislation in order to determine whether the legislation provides a real or perceived increase in security for Canadians, and how this legislation stands up to the Canadian Charter of Rights and Freedoms.

\section{U.S. Hegemonic Influence on Canada's Sovereign Domestic Policy-Making}

The asymmetrical power relationship between Canada and the United States played a major role in Canada's policy-making decisions in the aftermath of 9/11. As North America was stricken with terror, governments capitalized on the heightened fear of the nation in order to rapidly advance controversial political agendas (Kellner, 2004). Sharing the longest undefended border with the United States, Canada was in a particularly unique situation in regards to anti-terrorism legislation. Although Canada was not directly in a state of emergency following 9/11, the United States chose to exercise their political influence over Canadian governments in order to ensure the safety and security of Americans (Biswas, 2009).

A key concern for the American government was border control. In order to protect American national security, the government wanted to change how easily accessible the flow of goods and people into the country was (Biswas, 2009). State borders play an important role in both the political functioning of a state and its economic standing with bordering countries. Borders mark out a state's territory, declare and exert national sovereignty, and "their selective permeability operates as a measure of the nation-state's security against external threat" (Macklin, 2001). A country's sovereignty over its state borders means that the country has the sole ability to 
control behaviour within the state borders, and the power to control movement across them. State governments must also have the capacity to make uninfluenced policy decisions within these borders (Biswas, 2009).

Canada's asymmetrical interdependent relationship with the United States resulted in the United States exercising hegemonic power over Canada's sovereign border policies, and limited Canada's ability to control their own border policies (Biswas, 2009). In particular, the American government scrutinized Canada's immigration and refugee policies, noticing existing terrorist activity in Canada, and feared that these groups would be able to permeate American borders due to lax border security (Biswas, 2009). In response to 9/11, the United States government gave Canada two options: either modify existing domestic policies so that they fit in line with the American interests of heightened national security, or else Canada would face more restrictive border controls. This hegemonic exercise of political power outside of American borders sought to limit Canada's autonomy over its domestic policy, thus infringing on Canada's own sovereignty (Biswas, 2009).

An American decision to tighten border security would have major economic implications for Canada, as the United States is Canada’s largest trading partner. In 2010, Canada exported \$2.9 billion of goods to the United States, accounting for $73.3 \%$ of the country's total exports. In addition, Canada imported $\$ 2.6$ billion of goods from the United States, accounting for $62.8 \%$ of Canada's total imports (Statistics Canada, 2012). However, Canada's economic relationship with the United States is very one-sided. In 2012, exports to Canada made up only $17.0 \%$ of total U.S. exports, and imports from Canada accounted for only $14.2 \%$ of total imports (U.S. Department of Commerce, 2013). The diversified economy of the United States would not be as drastically harmed by increased border control with Canada. The threat of economic sanctions forced 
Canadian politicians to react rapidly to the threat of terrorism, and pass legislation that conformed to American interests.

\section{Canada's Anti-Terrorism Legislation}

The result of this hegemonic influence from the United States was Canada's Anti-terrorism Act (Bill C-36). The bill was introduced into the House of Commons for its first reading on October 15, 2001, and received royal assent on December 18, 2001, a mere 3 months after the events of 9/11. The Anti-terrorism Act was a response to issues of national security and it altered many pieces of legislation. The full title of the Act is cited as: "An Act to amend the Criminal Code, the Official Secrets Act, the Canada Evidence Act, the Proceeds of Crime (Money Laundering) Act and other Acts, and to enact measures respecting the registration of charities, in order to combat terrorism" (Anti-terrorism Act, 2001). Bill C-36:

introduced new and potentially dangerous legal concepts such as investigative hearings, preventive arrests, broad motive-based crimes based on participation in or contribution to terrorist groups at home or abroad, as well as new powers to list terrorist groups, take their property, and deprive suspected terrorists of sensitive security information in their trials and appeals. (Roach, 2002)

The bill also ratified two United Nations Conventions: the International Convention for the Suppression of the Financing of Terrorism and the International Convention for the Suppression of Terrorist Bombings (Lennox, 2007).

The new provisions of the Anti-terrorism Act did not come without a price tag. Funding to support the implementation of the increased security measures amounted to $\$ 7.7$ billion over five years, which was announced by then finance minister Paul Martin in the December 2001 federal budget (Lennox, 2007). This sum of money was "proportionately larger than the US allocation to the same objectives" (Clarkson, 2003). 
The bill received very minimal public input before being passed as law in Canada despite the fact that it drastically increased the investigative and surveillance capabilities of the government (Lennox, 2007). The Liberal government presented a time allocation motion on Bill C-36 after only four-and-a-half hours of debate in order to limit the amount of discussion on the bill. They also used a process called pre-consultation, used in the Senate, in order to push the bill through Parliament as quickly as possible (Lennox, 2007). Although Canada had not declared a state of emergency as the United States did following 9/11, it is evident that this legislation was introduced in a "climate of emergency" (Diab, 2008). It was necessary for legislation to be passed very rapidly through Parliament in order to capitalize on the spirit of urgency, as the United States viewed terrorism as a very imminent threat to the country.

\section{What is Terrorism? The Psychological Phenomenon of Terror and the Influence of Media}

Although Canada has taken drastic measures to increase national security, the question remains as to whether terrorism poses a real threat to society. In order to understand this issue, we must examine the definition of terrorism, and examine the motivations behind modern terrorist organizations. There is an interesting discrepancy between the mass media portrayal of terrorism and the political understanding of the term. The terms "terrorist" and "terrorism" have saturated mass media news outlets since 9/11 (Kellner, 2004). These words are used repeatedly to label certain groups in society, although no proper definition of the terms is ever explained. The word “terrorism" is very highly stigmatized, and it is often used indiscriminately (O’Neil, 2010). Before examining the mass media portrayal, it is important to dissect the true meaning of the term terrorism in order to understand the objectives of modern terrorist groups, and make an objective comparison to the media portrayal of the topic. 
To begin to understand the true definition of terrorism, it is important to analyse the meaning of the root word, of these two words, terror. The Oxford English dictionary defines terror as "extreme fear". The instillation of extreme fear into the mass population is what legitimizes acts of terror (Biernatzki, 2002). Terrorism, on the other hand, proves to be a much more difficult term to define. The United Nations has not been able to decide on a definition of the term, mainly because the term is used very differently by various state leaders. State leaders use the word terrorism whenever they find their state interests to be under threat; whether this is from liberation struggles, guerrilla war, or any other attempt to overthrow the political elite (Melnyk, 2010). Still, fear is the underlying concept that is consistent throughout all ideas of terrorism. State leaders fear that their state interests are at risk. Regardless of whether an objective definition of the word terrorism is reached, it is clear that this emotion of fear and terror is the fundamental theme in all situations where the word terrorism is used. "Terrorism is the intentional generation of massive fear by human beings for the purpose of securing or maintaining control over other human beings" (Cooper, 2001). Fear is the primary mechanism by which terrorist organizations seek to gain control over populations and further their own political agendas. Whether this is achieved through actual violence, or merely the threat of violence, implanting fear into the minds of the target group is what makes an act of terrorism successful. Terror is largely a psychological phenomenon; it has the power to immobilize people, and coerce them into action.

The mass media has done a successful job at legitimizing the threat of terror in the minds of North Americans, and perpetuating the "Us vs. Them" ideology that terrorism is an inherent component of Islamic cultures. North Americans have come to understand the word "terrorism" as "a violent act against an innocent population perpetrated by heartless, fanatical enemies of that population or its government, whose only goal is death and destruction" (Melnyk, 2010). The mass 
media, as well as politicians promoting this anti-terrorism legislation, have stripped the political and moral justifications from acts of terrorism, and replaced these with ideas of fear and loathing towards particularly Middle-Eastern nations (Melnyk, 2010). North Americans are fed images of Islamic groups on nightly news segments, as racialized headlines flash across the television screen. The idea that terrorism is an inherent part of the Muslim and Islamic culture instils additional fear in the minds of North Americans. Members of these minority groups are racially profiled and further victimized in society because they have been labelled as "Them", a distinct group in society whose cultural values are viewed as different and inferior from the Westernized norms.

In reality, terrorist groups have similar goals as politicians or journalists, and mass media ironically works to further these goals. These overlapping objectives include:

1. Access - getting prominent headlines and airtime.

2. Name recognition - getting one's name or organizational "brand" readily known.

3. Setting the agenda - gaining power to frame issues and set the terms of debate. (Widlanski, 2012)

When news headlines constantly feature stories about terrorist groups, emotions of fear and terror are instilled in media consumers, which is precisely the primary objective of an act of terror. Giving terrorist groups access to airtime maintains the emotion of terror in the public. Foremost, terror is a psychological phenomenon, and media access legitimizes this emotion, adding fuel to the fire of terrorism. In George Melnyk's essay titled “The Word 'Terrorism' and its Impact on Public Consciousness", Melnyk effectively explains this vicious circle that happens between the media and terrorism, and how this works to support government objectives:

When terrorism is put at the forefront of public concern, forces are unleashed that are profoundly anti-democratic. The word creates a demagogic atmosphere in which fear reigns supreme and that fear much be refreshed from time to time with real actions in the real world. When events labelled "terrorism" recede into memory and are not refreshed with fresh events so labelled, the term loses its potency as political explanation and mobilization. (Melnyk, 2010) 
The major issue with the media portrayal of terrorism is that media outlets fail to present an objective view of the issue. A notable news network that is notorious for this is $\mathrm{CNN}$, who because had become one of the most prominent media outlets following before the events of 9/11 (Saighal, 2004). CNN features news broadcasts that reflect the desires of the American government and is filled with misinformation and disinformation on the topic of terrorism (Saighal, 2004). Unfortunately, this results in only one side of the story being shared, which is advantageous for governments in their policy objectives (Melnyk, 2010). If mass media can maintain the emotion of fear in the minds of a country's citizens, it is more likely that the citizen's will support controversial policy objectives from the government that undermine the principles of democracy (Melnyk, 2010). Analysed through the structural functionalist perspective of society, legislation works to set a country's mind at ease. Confidence is the opposite emotion of terror, and the population is more likely to agree with the objectives of the government if they appear to be confident in their methods of eliminating terrorism (Melnyk, 2010). However, the function of media is to remind citizens of the potential for terror, forming a basis for the creation of these government policies. Thus, a full-circle effect occurs. If policy has done a successful job at creating a false sense of security in the minds of Canadians, the mass media has done an equally successful job at dismantling this security (Melnyk, 2010).

Politicians and academics are also largely concerned with the intentions of terrorists. Why do certain groups choose suicide bombings over car bombs? What motivated the al-Qaeda group to hijack two airplanes and fly them into the World Trade Centre buildings in New York? Understanding these intentions allows policy makers to understand why these acts occur, and to target certain acts with a through policy and to better understand why these acts occur. Aside from the primary goal of instilling fear, terrorist organizations are motivated by political, ideological, 
and religious reasons. Political terrorists are motivated by the desire to eliminate colonial rule and institute a change in political power. Religious terrorists work to assert their cultural beliefs, which they believe are superior to all other groups. Ideological terrorist groups are motivated by the desire to end economic oppression (Lauderdale \& Oliverio, 2005). The end objective is carefully outlined, and then a plan is developed with the intent of achieving this objective while simultaneously intimidating the authorities (Whittaker, 2002). Modern terrorist group activity must be considered in both the context of both historical and political contexts of the nation in order to understand the motivations behind the acts and predict future threats to society.

\section{Modern Terrorist Groups and their Motivations}

The Canadian government has faced challenges to terrorism on both a domestic as well as international front. In June of 2006, 18 individuals were arrested for plotting a series of attacks throughout southern Ontario. This terrorist plot became known as Toronto 18. One of the plans was to bomb the Toronto Stock Exchange as well as other prominent buildings throughout southern Ontario (CBC News, 2008). The group was attempting to create a large terrorist unit in Toronto, similar to that of al-Qaeda. The group wanted to arm themselves with weapons and wreak havoc in order to scare the Canadian public, and influence Canada to withdraw troops from Afghanistan, which was the primary political objective of their terrorist plot (CBC News, 2008).

There was a great amount of discrepancy between the actual facts in the Toronto 18 case, versus the media portrayal of the case. Prime Minister Stephen Harper publicly announced that the group of radicalized youths was motivated by a hatred of democracy, and were targeting Canadian values such as freedom and the rule of law (Miller \& Sack, 2008). Media outlets worked very closely with the Prime Minister's Office, and top bureaucrats provided instruction to politicians and security officials regarding what information to reveal in any interviews. The office also 
carefully monitored what was released to the public in order to ensure that all media coverage portrayed the idea that this domestic terrorist plot was inspired by Al-Qaeda, and would have had a magnitude similar to that of the Oklahoma City bombings if law enforcement hadn't apprehended the group (Miller \& Sack, 2008). A high level of fear was injected into the minds of Canadians by this media coverage. However, 15 months after the initial arrests, charges had been dropped against seven of the eighteen suspects. No evidence of radicalization, hatred of democracy, or any ties to Al-Qaeda terrorist groups were proven (Miller \& Sack, 2008). 1,700 pages of government correspondence obtained by the Globe and Mail proved that the Conservative government had monitored all media outlets, ensuring that the public had confidence that the government was fighting terror (Miller \& Sack, 2008). False motivations were portrayed to the public through the media, and the accused individuals were represented in a way such that the public saw their motivations that were radical and violent in nature, as compared to shadowing the actual legitimate political objectives of the group. The government had worked closely with the media in order to create a climate of fear and emergency, creating a perceived threat that was drastically larger than the real threat that the terrorist group posed.

In contrast to these this example of domestic terrorism, international terrorist organizations also plague North Americans with fear. The unprecedented events of 9/11 formed the basis for all modern anti-terrorism legislation in North America, and reinforced the constant racialization of terrorists by the mass media. Osama bin Laden and the al-Qaeda terrorist organization were motivated by both religious and political reasons. In bin Laden's "Letter to America" he begins by addressing Allah, explaining how believers are given permission to fight by Allah because they have been wronged (Bin Laden, 2002). Bin Laden also lists many political reasons for waging an attack against the United States. These include previous American attacks in Palestine and 
Somalia, America's dominance in the global oil market, America's control of Iraq, and various reasons involving America's wealth as well as support of the Jewish population (Bin Laden, 2002).

What is unknown by many people is that although the attack on the World Trade Centres caused an unparalleled number of civilian casualties for a single act of terrorism, this high death toll was unintended. Osama bin Laden recorded a video from the depths of a cave, in which he outlined his Vision for the World. In this video, bin Laden outlined his preparations for the attack on New York City. When speaking about the planned magnitude of the attack, he said:

[W] calculated in advance the number of casualties from the enemy, who would be killed based on the position of the tower. We calculated that the floors that would be hit would be three or four floors [...] I was thinking that the fire from the gas in the plane would melt the iron structure of the building and collapse the area where the plane hit and all the floors above it only. This is all that we had hoped for. (Whittaker, 2002)

Although citizen casualties were still planned into the attack, it is interesting to note that the original plan for the attack was not motivated by a mass killing of American civilians. The attack's primary objective was political, and it was justified through religious means (Bin Laden, 2002). Again, it is evident that the use of mass media has affected perceptions of terrorist motivations. Media outlets label Islamic terrorist groups as a distinct culture in which violence is an inherent element (Smith, 2013). However, it is clear that there are political, religious, and ideological justifications behind the actions.

\section{Terrorism: A Real or Perceived Threat to Society?}

After carefully considering the concept of terrorism, the influence of the media, and the actual objectives of modern terrorist plots, the question arises as to whether terrorism is a real threat to society, or whether this fear is merely a psychological phenomenon, legitimized by governments to further their political objectives and undermine democracy. Terrorist groups do 
post a legitimate threat to society. Terrorist groups target public locations, and put the lives of civilians at risk in order to further their objectives. Whether or not the terrorist group has the intent to harm civilians, the risk is still present due to the nature of their activities. For example, Osama bin Laden claimed that his terrorist organisation did not intent to collapse both of the World Trade Centres, killing 3,000 American citizens (Bin Laden, 2002). However, they still had the intent to fly the two airplanes into the towers and kill a number of civilians. Evidently plans do not always proceed as expected, but the magnitude of harm was certainly reasonably foreseeable.

Terrorism also poses real threats to both the economic and political stability of a nation. Highly publicised and effective terrorist attacks are successful in depressing tourism, reducing foreign investment into a country, and harming the stock markets (O'Neil, 2010). Politically, terrorist groups pose a threat to the governing regime of the country, and the democratic function of the state in North America. As citizens constantly see images of terrorist activity on news programs, the people may begin to lose faith in the government if it does not allocate a significant amount of resources towards combating terrorism. In achieving this goal of greater national security, a trade-off occurs between civil liberties and state authority, leading to a breakdown of democratic institutions (O'Neil, 2010). Canada's Anti-terrorism Act was passed through parliament during a time of heightened national fear. This government response was intended to reassure Canadians that their safety and security was of primary importance, generating national support for the legislation. However, the demagogic method that the government used in order to create this support suggests that perhaps terrorism doesn't pose as imminent of a threat to society as the media portrays. If governments are relying on emotionally based arguments to support the threat of terrorism rather than concrete evidence, concerns are raised as to what the real objectives 
of government actions are, and whether this psychological phenomenon of terror is being strategically used to gain support for controversial legislation.

\section{Implications of Anti-terrorism Legislation on Canadian Charter Rights}

Several aspects of Canada's Anti-terrorism Act have come under scrutiny for their adherence to democratic principles, and the constitutionality of the Act. As previously mentioned, Canada did not declare a state of national emergency following the events of $9 / 11$. However, the Anti-terrorism Act was still rapidly passed through Parliament with a spirit of urgency, despite the insistence from the Canadian government that it was not a piece of emergency legislation (Weinrib, 2001). During debate over the bill, reference was made to the War Measures Act of 1914, and politicians argued that the Anti-terrorism Act was constitutionally sound because the War Measures Act justified the authorization for emergency executive state power in times of crisis. Interestingly, the War Measures Act was repealed and replaced with the Emergencies Act in 1988, but no reference to the later Act was mentioned in debate (Weinrib, 2001). Considering that the Anti-terrorism Act was not considered emergency legislation, and the basis for its justification was a repealed act whose purpose was to justify state power in emergency situations, the constitutionality of the Anti-terrorism Act remains a major political issue. It is also interesting to note that a sunset clause was not included in the legislation. A sunset clause would require that the legislation be reviewed for constitutionality after a certain time period has passed. The lack of this sunset clause made many of these controversial new executive powers permanent (Diab, 2008).

Emphasis on government power is also evident in the change of rhetoric used in Parliamentary debate between the first and third readings of Bill C-36. When the bill was proposed in the first reading on October 15, 2001, then Minister of Justice Anne McLellan assured Canadians that "Charter rights [had] been considered and preserved against the objectives of 
fighting terrorism and protecting national security" (Diab, 2008). During the third reading of the bill, emphasis for the bill's justification transitioned to primarily security-centred concerns. McLellan stated that:

Now is the time to move forward. Canadians expect their government to act to ensure their security and safety. [...] What we are doing in Bill C-36 [...] is putting in place the legal and operational infrastructure necessary to provide Canadians with that degree of safety and security that permits them to get on with their lives. (Diab, 2008)

What can be taken from this argument is that the Anti-terrorism Act was a response to this psychological phenomenon of terror. McLellan states that the purpose of Bill C-36 is to allow Canadians to "get on with their lives" and move beyond the state of fear caused by $9 / 11$, into a state of security and confidence in the government.

Specific provisions created by the Anti-terrorism Act also raised cause for alarm, as violations of Charter rights became an issue of concern. In particular, the offence of "facilitating" an act of terrorism and the vague mens rea elements of this offence has been challenged in Canadian Courts (Diab, 2008). The full provision, section 83.19 of the Criminal Code, can be found in Appendix A. This provision has been criticized as having eradicated the fault element in criminal law. A person could be charged under this offence without knowing they were in fact facilitating terrorism (Diab, 2008). It has been argued that "the only remaining fault element [in the offence] would be failing to take reasonable care to ensure that what was being facilitated was actually not a terrorist activity" (Diab, 2008).

Momin Khawaja, the leader of the Toronto 18 terrorist plot, was the first person to be convicted under Canada's Anti-terrorism Act in 2008. He was found guilty of five charges of financing and facilitating terrorism, and two Criminal Code offences related to building explosive devices (MacCharles, 2008). He was originally sentenced to $101 \frac{1}{2}$ years in prison, but the sentence 
was increased to life in prison with no chance of parole for 10 years by Ontario's Superior Court of Justice (MacCharles, 2008). Khawaja argued under section 52(1) of the Canadian Constitution that certain provisions of section 83 of the Criminal Code were inconsistent with the Constitution, therefore they should be of no force or effect. Khawaja claimed that "the provisions are vague and/or over-broad, they dilute the essential fault requirements of criminal law, and they infringe [the] rights of association, freedom of conscience and religion, and freedom of thought, belief, opinion, and expression pursuant to section 2 of the Charter" (Diab, 2008). The Court upheld the decision that the provision was not vague because they had "sufficiently clear meanings" $(R v$ Khawaja, 2012 SCC 69, 3 SCR 555). Khawaja also challenged the inclusion of political, religious, and ideological objectives in the Court's definition of a terrorism offence, arguing that the labelling of these motives cases a chilling effect over minority groups in Canada, violating section 2 Charter. The Court agreed with Khawaja that this was a prima facie infringement of rights, but that it was justified under section 1 of the Charter because this violation represented a minimal infringement on the rights in order to protect Canadian interests (R. v. Khawaja, 2012 SCC 69, 3 SCR 555). This case was the first major challenge for Canada's new Anti-terrorism Act in the Canadian courts.

\section{Conclusions: The Justification of Charter Rights Violations in a Democratic Society}

The justification of anti-terrorism legislation in Canada is evidently a process in which Canadians see limitations placed on their Charter rights. This challenge to the democratic functioning in Canada began following the events of 9/11, when the United States gave Canada two options in terms of domestic policy: to either implement policy in line with American interests, or face harsh border restrictions. American hegemonic influence also infiltrated the media, which is the primary mechanism used to instil fear into the minds of citizens. As people are constantly 
presented with images and ideas of non-Westernized cultures as inherently violent, fear begins to creep into domestic life as well. Canadian governments capitalized on this fear by implementing the controversial Anti-terrorism Act in December of 2001, and put the minds of Canadian citizens at ease by sending the message that national security was a high priority. However, the media does an excellent job at camouflaging the true motives of terrorist organizations. In the Toronto 18 case, it was revealed that the Canadian government was working hand-in-hand with media outlets to amplify fear. This demagogic effect, where false reasons were portrayed based on emotion, connects the issue of anti-terrorism legislation full-circle: terrorist groups portray fear, the media amplifies the fear, and governments capitalize on these skewed media messages. Although politicians claim that anti-terrorism legislation is in the best interests of Canadians, and the violation of Charter rights is justified, these issues are still up for contest. With the recent Supreme Court review of the R. v. Khawaja in 2012 it is clear that the provisions of the Anti-terrorism Act still remain an area for debate 12 years after its implementation. Acts of terrorism, although few and far between in Canada, do pose a real threat to the safety of Canadians. However, the primary motivation of terrorist acts in instilling terror in the minds of civilians, not mass killing, as is depicted by the media. If the mass media presented an objective view of terrorist motivations rather than amplifying terror in the minds of North Americans, Canadians may have a significantly different view about the democratic function of the state and Canada's Anti-terrorism Act. 


\section{Appendix A: Section 83.19 of the Criminal Code}

\section{Facilitating terrorist activity}

- $\quad 83.19$ (1) Every one who knowingly facilitates a terrorist activity is guilty of an indictable offence and liable to imprisonment for a term not exceeding fourteen years.

-

- (2) For the purposes of this Part, a terrorist activity is facilitated whether or not

- $\quad($ a) the facilitator knows that a particular terrorist activity is facilitated;

- $\quad(b)$ any particular terrorist activity was foreseen or planned at the time it was facilitated; or

(c) any terrorist activity was actually carried out.

(Criminal Code, RSC 1985, c C-46, s. 17; RSC 1985, c 27 [1 st Supp]) 


\section{References}

Anti-terrorism Act, SC 2001, c C-41, online: Department of Justice Canada <http://lawslois.justice.gc.ca/eng/acts/A-11.7/FullText.html>.

Biernatzki, W. E. (2002). Terrorism and Mass Media. Communication Research Trends, 21:1. 325.

Bin Laden, O. (2002). Letter to America. Retrieved December 3, 2013 from <http://www.theguardian.com/world/2002/nov/24/theobserver>.

Biswas, B. (2009). Just Between Friends: Bilateral Cooperation and Bounded Sovereignty in the "Global War on Terror". Politics and Policy, 37:5. 929-950.

CBC News. (2008). Toronto 18: Key Events in the Case. Retrieved December 2, 2013 from $<$ http://www.cbc.ca/news/canada/toronto-18-key-events-in-the-case-1.715266\#timeline>.

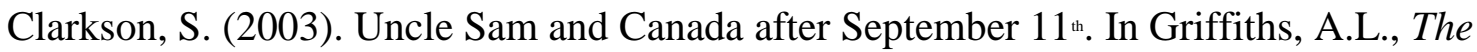
Canadian Forces and Interoperability: Panacea or Perdition? (77-88). Halifax, NS: Centre for Foreign Policy Studies, Dalhousie University.

Combating Terrorism Act, SC 2013, c. 9, online: Department of Justice Canada <http://lawslois.justice.gc.ca/eng/annualstatutes/2013_9/page-1.html>.

Cooper, H. (2001). Terrorism: The Problem of Definition Revisited. American Behavioural Scientist, 44:6, 881-893.

Criminal Code, RS.C 1985, c C-46, s. 17; RSC 1985, c.27 (1st Supp). Retrieved online December 3, 2013 from <http://laws-lois.justice.gc.ca/eng/acts/c-46/page35.html\#docCont>.

Diab, R. (2008). Guantánamo North: Terrorism and the Administration of Justice in Canada. Black Point, NS: Fernwood Publishing.

Kellner, D. (2004). 9/11, Spectacles of Terror, and Media Manipulation: A Critique of Jihadist and Bush Media Politics. Critical Discourse Studies, 1:1. 41-64.

Lauderdale, P. \& Oliverio, A. (2005). Terrorism as Deviance or Social Control: Suggestions for Future Research. International Journal of Comparative Sociology, 46;1-2. 153-169.

Lennox, P. (2007). From Golden Straitjacket to Kevlar Vest: Canada's Transformation to a Security State. Canadian Journal of Political Science, 40:1. 1017-1038.

MacCharles, T. (2012). Supreme Court of Canada Upholds Anti-terror Law; Khawaja's Appeal Rejected. Toronto Star Newspapers. Retrieved December 2, 2013 from 
<http://www.thestar.com/news/canada/2012/12/14/supreme_court_of_canada_upholds_ant iterror_law_khawajas_appeal_rejected.html>.

Macklin, A. (2001). Borderline Security. In Daniels, J., Macklem, P. \& Roach, K., Essays on Canada's Anti-terrorism Bill (383-404). Toronto, ON: University of Toronto Press.

Melnyk, G. (2010). The Word "Terrorism” and Its Impact on Public Consciousness. In Kassam, K.S., Understanding Terror: Perspectives for Canadians (101-123). Calgary, AB: University of Calgary Press.

Miller, J. \& Sack, C. (2008). Terrorism and Anonymous Sources: The Toronto 18 Case. Ryerson University.

O’Malley, M. (2003). Canada and the US After 9/11. CBC News. Retrieved December 2, 2013 from <http://www.cbc.ca/canadaus/omalley1.html $>$.

O’Neil, P. H. (2010). Essentials of Comparative Politics, Third Edition. New York, NY: W. W. Norton \& Company Ltd.

$R v$ Khawaja, 2012 SCC 69, 3 SCR 555. Retrieved online December 3, 2013 from <http://scccsc.lexum.com/decisia-scc-csc/scc-csc/scc-csc/en/item/12768/index.do>.

Roach, K. (2002). Did September 11 Change Everything? Struggle to Preserve Canadian Values in the Face of Terrorism. McGill Law Journal, 47:4. 894-947.

Saighal, V. (2004). Dealing with Global Terrorism: The Way Forward. Elgin, IL: New Dawn Press Group.

Schuster, M. A., Stein, B. D., et al. (2001). A National Survey of Stress Reactions after the September 11, 2011 Terrorist Attacks. The New England Journal of Medicine, 345:20. 1507-1512.

Smith, C. (2013). Anti-Islamic Sentiment and Media Framing during the 9/11 Decade. Journal of Religion and Society, 15. 1-15.

Statistics Canada. (2012). Canada at a Glance: International Trade. Retrieved December 1, 2013 from Statistics Canada <http://www.statcan.gc.ca/pub/12-581-x/2012000/it-cieng.htm>.

U.S. Department of Commerce. (2013). U.S. Census Bureau: U.S. International Trade in Goods and Services. Retrieved December 1, 2013 from <http://www.census.gov/foreigntrade/Press-Release/current_press_release/ft900.pdf $>$.

Weinrib, L. (2001). Terrorism's Challenge to the Constitutional Order. In Daniels, J., Macklem, P. \& Roach, K., Essays on Canada's Anti-terrorism Bill (93-108). Toronto, ON: University of Toronto Press. 
Whitaker, R. (2003). Keeping Up with the Neighbours: Canadian Responses to 9/11 in Historical and Comparative Context. Osgoode Hall Law Journal, 41:2. 241-265.

Whittaker, D. J. (2002). Terrorism: Understanding the Global Threat. Great Britain: Pearson Education Limited.

Widlanski, M. (2012). Battle for our Minds: Western Elites and the Terror Threat. New York, NY: Threshold Editions. 